\title{
Negotiating Social Boundaries and Private Zones: The Micropolitics of Employing Migrant Domestic Workers
}

\author{
PEI-CHIA LAN, National Taiwan University
}

\begin{abstract}
The employment of migrant domestic workers has turned the private home into a contested terrain where employers and workers negotiate social boundaries and distance from one another on a daily basis. Based on indepth interviews with Taiwanese employers and Filipina migrant workers, this article explores how the groups negotiate two sets of social boundaries in the domestic politics of food, space, and privacy: socio-categorical boundaries along the divides of class and ethnicity/nationality, and socio-spatial boundaries segregating the private and public spheres. Along these two dimensions I create two typologies to analyze a variety of boundary work conducted by employers and workers in this global-local, public-private matrix.
\end{abstract}

Domestic service, linked to the dark histories of slavery and colonialism, has long indicated class and racial hierarchies in the private domain. Today, increasing international migratory flows have brought even more women to work in foreign households around the globe. A private household has now become a microcosm of social inequalities in the global economy. Migrant domestic workers are the perfect example of the intimate Other-they are recruited by host countries as desired servants and yet rejected citizens; they are termed "part of the family" by their employers while being excluded from the substance of family lives.

Drawing on a qualitative study of Taiwanese domestic employers and Filipina migrant workers, this article explores "boundary work" in the micropolitics of domestic employment. The hiring of foreign domestics demonstrates the process of establishing, reproducing, and contesting social boundaries between "us" and "them." The domestic politics of food and spaceeating meals, distributing food, utilizing home space, and delimiting privacy-involves daily rituals and practices through which both employers and workers negotiate class and ethnic distinctions and organize the public/private spaces in the fabric of family life.

\section{Boundary Work in Domestic Employment}

Evelyn Nakano Glenn (1986) identifies two complementary features of domestic employment: personalism and asymmetry. A sense of personal intimacy can make employment relations seem like family ties, but substantial status difference exists between employers and domestic workers. Such an ironic contrast is particularly evident in the employment of migrant

The author is grateful to Carol Heimer, Gary Alan Fine, Orville Lee, Charles Ragin, Pierrette Hondagneu-Sotelo, and Gwo-Shong Hsieh for their comments on previous drafts. The author also thanks James Holstein and the anonymous reviewers of Social Problems for their suggestions and encouragement. Students in the graduate seminar Sociology of Gender (Fall 2001) and the audiences at Tsing-Hua University and Academia Sinica were excellent readers as well. This research was funded by a Dissertation Year Fellowship at Northwestern University, Chiang Ching-Kwo Foundation, and the Institute of Sociology at Academia Sinica. Direct correspondence to: Pei-Chia Lan, Department of Sociology, National Taiwan University, Taipei, Taiwan, 106. E-mail: pclan@ntu.edu.tw.

SOCIAL PROBLEMS, Vol. 50, No. 4, pages 525-549. ISSN: 0037-7791; online ISSN: 1533-8533

(C) 2003 by Society for the Study of Social Problems, Inc. All rights reserved.

Send requests for permission to reprint to: Rights and Permissions, University of California Press,

Journals Division, 2000 Center St., Ste. 303, Berkeley, CA 94704-1223. 
domestics, which produces an interpersonal encounter across cultural and national borders. However, "the threat of mixing is countered by established rituals" (Ozyegin 2001:11). Interactions between social groups do not always undermine, but often enhance, the boundaries that divide them.

To examine the micropolitics of hiring migrant domestics, I turn to the concept of "boundary work," which has been developed in the recent literature of cultural sociology. In general, this concept consists of "the strategies, principles, and practices we use to create, maintain, and modify cultural categories" (Nippert-Eng 1995:7). It is an "intrinsic part of the process of constituting the self": we define who we are by drawing inferences concerning our similarity to, and differences from, others (Lamont 1992:11). Boundary work involves specific sets of social boundaries in various settings. Christena Nippert-Eng (1995) discusses how employees negotiate the home/work boundary by organizing realm-specific matters, people, objects, and aspects of the self. Michèle Lamont (2000) uses this concept to describe class identification of black and white working-class men: they define who they are by establishing moral boundaries between "people like us" and others.

I use the concept of "boundary work" as a theoretical tool to analyze the ways that employers and workers negotiate two intersecting sets of social boundaries. The first set consists of socio-categorical boundaries along the divides of class and ethnicity/nationality. Feminist literature has pointed out structural patterns of exploitation between maids and madams, and I further explore the interactive dynamics of reproducing and negotiating social inequalities. Secondly, I examine socio-spatial boundaries that circumscribe the province of domesticity and privacy. Such boundary work is particularly vital in the employment of migrant domestic workers, who usually live in the homes of their employers. In these cases, boundary work is not only an interactive practice of constituting self and identity, but also an intrinsic part of the process of reproducing and contesting social inequalities. Dominant social groups such as employers tend to maintain the status quo, whereas minority groups like workers attempt to make the boundaries permeable or to construct alternative boundaries.

Although the theme of boundary work has yet to be explicitly discussed in the literature of domestic work, previous studies have shed light on the negotiation of social distance between employers and workers. Judith Rollins (1985) observed that white employers in Boston played the role of benevolent mother as a way of confirming the inferior status of colored workers. Pierrette Hondagneu-Sotelo's (2001) interviews of contemporary domestic employers in Los Angeles resulted in even broader findings. Although maternalistic acts are still prevalent among wealthy homemaker employers, middle-class double-earner families have neither time nor energy to cultivate personal ties with domestic workers. They maintain a distant relationship with part-time housecleaners, or they deploy "strategic personalism" with live-in nannies only to ensure the quality of care work.

Workers also negotiate the social distance with their employers in distinct ways and for various reasons. Latina day workers and part-time cleaners in the studies of Mary Romero (1992) and Leslie Salzinger (1991) "upgrade" this occupation by establishing a business-like contractual relationship. However, Jennifer Mendez (1998) interviewed cleaners employed by a bureaucratic agency and found that many workers actually prefer private employment, in which they have the autonomy of selecting employers and can obtain personal favors. Turkish maids and doorkeepers interviewed by Gul Ozyegin (2001) even embrace class hierarchies because they gain raises and extra benefits in a patron-client relationship. In addition, newly arrived migrants tend to choose live-in work to minimize expenses and alienation in a new country (Anderson 2000:40). Many live-in workers crave personal contact with their employers, viewing personalism as an avenue for employers to show respect for them as people (Hondagneu-Sotelo 2001).

This wide range of observations demonstrates that neither employers nor domestic workers are monolithic groups. They develop different preferences and strategies given their particular social positions, job descriptions, and employment conditions. Therefore, I establish 
typologies to analyze how and why employers and workers adopt a variety of approaches to boundary work. I also point out three major structural factors to explain their distinct preferences toward certain types of boundary work: first, class positioning-the disparity or similarity between the employer's class position and the worker's previous background; second, job assignment - the ratio of care work to housework involved in the job content; ${ }^{1}$ third, the timespace setting of the employment-how much extra time and space the employer has and how much time the employer and worker spend together at home. These structural factors knit together a complex map that coordinates a variety of subjective dispositions shaping the interactive dynamics between employers and migrant domestics.

This article also examines how boundaries are negotiated between the private and public spheres. When the home becomes a workplace, both employers and workers must redefine and safeguard their private zones. The private image of family life is a historical product of Western capitalism associated with the division between production and reproduction; family/ home is defined as a private haven and an intimate environment sheltered from the chaotic public world (Cheal 1991; Lasch 1977). ${ }^{2}$ Borrowing the metaphor of Erving Goffman (1959), Arlene Skolnick (1992) describes family life as a "backstage area" that harbors secrets and behaviors only accessible to insiders. My analysis follows the ethnomethodologically-informed constructionist approach of James Holstein and Jaber Gubrium (1995), who view family as a "socially constructed, situationally contingent cluster of meanings" (p. 896). Rather than treating family boundary as a given entity, I explore the interactive construction of private domesticity by studying the dynamics of employing "outsiders" in the homely backstage.

The boundary work in domestic employment relationships is situated in the domestic politics of food, space, and privacy. Previous studies have pinpointed the significance of preparing and eating meals in the maintenance of family ties. Mealtimes provide a routinized setting for sharing information, coordinating activities, and transmitting social norms and cultural values among family members (McIntosh 1996). The preparation of family meals involves the affective work of "constructing the family" based on tacit knowledge about family members' tastes and nutritional needs (DeVault 1991). The consumption of food in a household also marks status hierarchies among family members according to age, gender, and economic responsibility. ${ }^{3}$ Similarly, food management becomes a crucial mechanism by which employers define the marginal status of domestic workers in the household (Colen 1986; Romero 1992). Employers mark family boundaries through the arrangement of eating meals-who is included at the dining table, where to sit at the table, who eats before or after whom-as well as the distribution of food-who gets more food, better quality, and a larger variety, and whose tastes or needs are prioritized.

The deployment of home space is another critical practice that delimits and affirms family boundaries; it also symbolizes status distinction among members present in the house. Previous literature has documented how employers and domestic workers have unequal rights to the use of space (Constable 1997a; Rollins 1985); the old-fashioned "upstairs, downstairs" model in particular embodies the master-servant segregation (Ozyegin 2001). In Taiwan and other Asian host countries, spatial arrangements like separate entrances, separate stairwells, outdoor toilets, and servants' quarters are rarely seen. Considering the modest living space of

1. Hondagneu-Sotelo (2001:193) also argues that the extent to which care work is involved has a substantial impact on the preference of domestic workers in Los Angeles toward personalistic employment relations.

2. It is crucial to examine the discursive construction of private domesticity in Taiwan's social and cultural contexts, which is strongly associated with the changing household patterns and family relations. Yet this is beyond the scope of this article.

3. According to Christine Delphy and Diana Leonard (1992), the food in a household is often chosen to suit the taste of the head of the family; women and children often eat separately from men and they get smaller portions or food of lesser quality. 
most households, intrusion on privacy is almost unavoidable for both employers and domestic workers.

Privacy, defined as a state of "social inaccessibility" (Zerubavel 1981:138), is established through guarding access not only to physical space, but also to personal details. Domestic workers can easily access family secrets of their employers and learn about the quarrels and even the sex lives of their employers. Employers might either loathe the presence of an outsider in their home or actively disclose personal information to the workers. Workers might perceive the role of confidant either as evidence of personal ties with their employers or as an extra job requirement and emotional burden. Although the protection of privacy concerns both employers and workers, privacy is nevertheless a right unequally distributed along class lines. As Barry Schwartz (1968) points out, the privacy of upper ranks in an organization is insured structurally by the mediation of a lieutenant stratum; yet the privacy of lower ranks is more easily invaded since members of the lower rank enjoy less control over those who may have access to their privacy. In other words, the negotiation of the private zone is intertwined with the struggles over class and ethnic distinctions.

Recent literature has looked at the experiences of Third World women who migrate to foreign countries to pick up household and caring labor left by more privileged women. ${ }^{4}$ Their service to globalization is often overlooked because of their skin color as well as the privatization of their employment conditions. They are the "diasporic homeless," who endure the pain of family separation while feeling not "at home" in the employer's household. To safeguard their private zones, migrant workers have to go "public" to expand their life domains. Brenda Yeoh and Shirlena Huang (1998) describe such strategies of negotiating public space as "the colonization of prime public areas" (p. 593). On Sundays, migrant workers gather at "weekend enclaves" in host cities, such as Lucky Plaza in Singapore, Central District in Hong Kong, and the main train station in Taipei. These public places, away from their employers' homes, ironically become a "backstage area" that shelters these "homeless" migrants. To summarize, the employment of migrant domestic workers is a public-private, local-global matrix that demonstrates complex identity politics and boundary work in the context of global migration.

\section{Data and Methods}

Taiwan has opened the gate for migrant domestic workers since the early 1990s. This policy is presented as a cost-saving solution to the growing demands for paid childcare and eldercare among the expanding nuclear households and aging population. The government has adopted a system of quota control and contract employment to regulate the number of weilao (foreign workers) ${ }^{5}$ and to prohibit them from permanent settlement. Each worker can stay in Taiwan no longer than six years and cannot transfer employers freely. Despite the qualification of employers being subject to strict regulation, ${ }^{6}$ the number of Taiwanese households

4. Much literature has contributed to the discussion of international division of reproductive labor and transnational care work; see, in particular, Anderson (2000), Chang (2000), Parrenas (2001), and the volumes edited by Momsen (1999), and Ehrenreich and Hochschild (2002).

5. This term usually refers to foreign contract workers employed in $3 \mathrm{D}$ (dirty, dangerous, and demeaning) sectors only. The work permits of foreign professionals, technicians, and managerial workers are approved on a case-by-case basis without the quota restriction and they are entitled to permanent residence after working in Taiwan with legal jobs for over five years.

6. Taiwan's government first granted work permits to "domestic caretakers" who were employed to take care of the severely ill or disabled, and later released a limited amount of quotas for the employment of "domestic helpers" to households with children under the age of 12 or elderly members above the age of 70 . Currently, the government has almost stopped releasing quotas for the employment of domestic helpers, but places no quota restriction on the employment of migrant caretakers. Many households thus apply for caretakers with forged documents, but in fact assign them household chores or childcare. 
employing foreign domestics has rapidly increased within a decade. Currently over 120,000 migrant women, coming from Indonesia, the Philippines, and Vietnam, are legally employed as domestic workers in Taiwan (CLA 2003).

As a result of the introduction of foreign workers, domestic service in Taiwan is now provided by an ethnically stratified labor force who are associated with distinct employment arrangements. Migrant domestic workers are paid the minimum wage in Taiwan (NT\$15,840, approximately US\$460) and they usually have to reside with their contract employers. ${ }^{7}$ Taiwanese in this occupation are mostly day workers and part-time cleaners; they not only receive higher wages, but also enjoy greater flexibility and autonomy than their foreign counterparts (Lin 1999). The employment of migrant domestic workers is characterized by both the proximity of physical space (the live-in condition) and the width of social distance (distinct class positions and citizen statuses between employers and workers).

This research focuses on the experiences of Filipina migrant workers, who constitute a major labor source for domestic service worldwide. They secure a competitive advantage in the global labor market because of their education and English proficiency. A significant number of them have some college education or previously held professional occupations, such as teacher or nurse, in the Philippines. They experience what Rhacel Parrenas (2001) calls "contradictory class mobility" - taking on unskilled and demeaning jobs while gaining higher wages overseas. Elsewhere (Lan 2003), I have discussed the way in which their encounters with Taiwanese newly rich employers ${ }^{8}$ become a critical site for the negotiation of class identity. This article aims to establish a general framework that maps out a variety of dispositions and strategies of how both employers and migrant workers negotiate social distance and boundaries in relation to one another.

My fieldwork was carried out between July 1998 and July 1999, including a one-year ethnographic observation in a Filipina migrant community and open-ended, in-depth interviews with both Taiwanese employers and Filipina domestics. I did volunteer work in a Catholic church-based NGO (nongovernmental organization) in Taipei, attended a variety of the Sunday social outings of Filipina migrants, and interviewed 58 Filipina domestic workers within and outside this community. The majority (33) were in their 30s, while 15 were in their 20s, and 10 were in their 40s. Twenty-three were single, 20 were married, and 15 were separated or widowed. One-third had a college degree; another third had received some college education; the rest were high school graduates. Their previous occupations varied, but none of them had been domestic workers in the Philippines. ${ }^{9}$ All my interviews and conversations with Filipina workers were in English. I tape-recorded most of the interviews, and took notes for informal interviews and conversations.

In the mean time, through snowballing contacts, I conducted interviews with 42 Taiwanese households that employ migrant workers. I interviewed the wife in 36 households, the husband in three households, and both the husband and wife in three families. Most of the interviewees ( 39 of 45) were between the ages of 31 and 50. In 70 percent of the households, at least one family member had a college degree or higher. With the exception of one household

7. Some exceptions are undocumented migrant domestics, who either overstayed a tourist visa or have "run away" from their contract employers. Many rent their own apartments and work as part-time cleaners, paid at an hourly rate similar to the rate for local cleaners. See Lan 2000 for more details. This article focuses on documented migrant workers only.

8. According to a survey conducted by the Taiwanese government, the majority of Taiwanese employers represent middle-class, dual-earner households where one or two members have a college education or higher (CLA 1999). Most of them have no previous experience of hiring a live-in local domestic worker. Only a small proportion of their parents had hired maids or nannies during their childhood. The expansion of the domestic employer strata results from the prevalence of inter-generational, upward mobility after rapid industrialization in Taiwan.

9. In the Philippines, 23 of the informants held service jobs like cashiers and secretaries; three were factory workers; six owned a small vending business; eight had professional jobs like teachers, nurses, real estate agents; 14 were homemakers; and four were students. 
wherein the employer was a single father, of the 41 female employers, seven were homemakers, 31 were full-time workers, and three were part-time workers. I conducted interviews with Taiwanese employers in Mandarin Chinese and translated any included quotes from them into English. The interviews, lasting from one to three hours, were all tape-recorded and fully transcribed.

There were only four instances wherein I interviewed both the worker and employer of the same household. Later in my research process, I decided to avoid this arrangement because I did not want my interview to become a job assignment that a worker could not refuse. Besides, it held the potential of hindering workers from building trust in me if they labeled me "the employer's friend." As such, I accessed only one side of the story in most employment relationships, and, accordingly, I present the boundary work of employers and workers in a separate manner. Yet, boundary work in an employment relationship is interactive by nature; I will address how the two typologies of boundary work match (or mismatch) in the conclusion.

\section{Employers' Boundary Work}

I start with a discussion of employers' boundary work, because they have the upper hand in shaping the dynamics of an employment relationship. Basically, employers are negotiating two primary sets of boundaries during their interactions with domestic workers: they determine to what extent they want to include or exclude domestic workers in the family, and they also consider whether to highlight or downplay hierarchical difference between themselves and the workers. Drawing on these two dimensions, I divide employers' boundary work into four categories: maternalism, personalism, distant hierarchy, and business relationship (see Figure 1). It should be kept in mind that the categories in my typologies are Weberian ideal types. In reality, they are more like a continuum along which individual employers lean toward one or more approaches of boundary work in shifting contexts. Also, boundary work does not necessarily describe intentional acts of employers and workers; more often, the parties act upon some tacit knowledge that frames their understanding of selves and others.

\section{Distant Hierarchy: "You're Not My Guest. You Work Here"}

I drove over an hour to Mrs. Lee's house, which is located in the northern hills of the Taipei basin. Mrs. Lee, now in her early 40s, became a full-time homemaker after marrying an owner of an investment firm. When I reached the front door of the Lee's newly renovated

\begin{tabular}{|c|c|c|}
\hline & \multicolumn{2}{|c|}{ Family Boundary } \\
\hline & Inclusion & Exclusion \\
\hline Highlighting & Maternalism & Distant Hierarchy \\
\hline Downplaving & Personalism & Business Relationship \\
\hline
\end{tabular}

Figure 1 • Typology of Domestic Employers' Boundary Work 
three-story house, a Filipina worker came to answer the door. She led me through to the living room, where generous snacks on expensive china plates awaited me. Mrs. Lee showed up a little later, greeting me with a warm smile. She never introduced the worker to me, although she called her in a few times, in a raised voice and an affected English accent, to replace the hot water for my tea during the interview.

An employment relationship of distant hierarchy is grounded in the deferential performance of domestic workers, which may be linguistic, gestural, spatial, or task-embedded (Goffman 1956; Rollins 1985). In Taiwan, domestic employers receive respectful terms like "Ma'am" and "Sir," while Filipina domestic workers are called by their first names or even assigned similar sounding Chinese names if the employers cannot pronounce their original English names. Some job requirements are aimed at making a ceremonial display of the workers' subservience. For example, some Taiwanese employers ask their domestic workers to open the door for them upon their arrival home, instead of opening the door for themselves. Some employers request the workers to answer the telephone, although they themselves are at home and the worker speaks little Chinese.

The consumption of food is another subject that symbolizes class hierarchy in an employment relationship. Both domestic workers and employers complained to me about this issue, the workers calling the employers "stingy" and the employers calling the maids "greedy." To some employers, especially women, the power to distribute food among members of the household signifies their control over the domestic sphere. Mrs. Lee, for instance, explained to me her rules of "food management":

My principle is that you are not our guest; you work here. I don't want you to take any food without my permission. This is my house. You have to follow my rule, so I can have everything here under my control. Although I'm very strict in this aspect, once in a while, I will buy some sweets for them and put them on their desks. But without my permission, even a piece of candy is not allowed.

What concerned Mrs. Lee was not food per se, but the control of its distribution. Food management in domestic employment involves, first of all, considerations of what should be eaten and by whom. Status distinctions between employers and maids are displayed by a hierarchical distribution of various kinds of food-expensive versus cheap, meat versus vegetable, subsistence meals versus snacks, and fresh food versus leftovers. Some employers even use separate refrigerators in the house to store the family's food and the maid's food. There is also a division in terms of how to eat and where to eat. Employment agencies often suggest that their employer clients have the migrant workers eat separately-at different tables or in different rooms, with different plates, or after the employers finish. This advice indicates a racist prejudice that views Southeast Asian migrants as uncivilized and unhygienic; eating separately also represents a daily ritual to symbolize, in the words of my interviewees, the "master-servant distinction."

The two parties under the same roof have a tacit agreement about the limited home space made available to domestic workers. When I asked the employers if they felt any inconvenience living with a non-family member, many gave an answer similar to this one:

Not at all! Because she knows how to be invisible! Whenever we watch TV in the living room or have guests over, she just hides herself in the balcony. She is well disciplined.

In general, other than her bedroom (if she has one), the deemed appropriate spaces for a domestic worker to occupy include the kitchen, the balcony, and the children's playroom. By contrast, the living room is reserved for the social activities of the employer's family. Spatial deference is clearly displayed in the floor plans of upper-class residences. The servants' quarters or the maid's room, usually of a limited size and with bad ventilation, can be found in the attic or basement in dramatic contrast to the spacious bedrooms in the main part of the house. 
Most upper-class employers had experience with hiring obasan, the term that refers to local domestic workers in Taiwan. Many shifted to migrant workers not to reduce employment costs, but because they were dissatisfied with the job performance and attitude of local domestic workers. Mrs. Chu, the wife of a chief executive officer in her mid-40s, has been a domestic employer for over 20 years. She described how she finally came to the decision to hire a migrant worker three years ago:

I heard many bad things about Filipina maids. I dared not try. At that time it was already very difficult to find live-in Taiwanese. The last obasan I hired charged me a lot and that one was quite arrogant. She didn't take your orders at all . . . One day my friend came to my house. She didn't even bother to answer the door. She just sat there and murmured, "Who's that?" So I had to open the door myself. My friend came in and saw an old woman sitting there-the obasan didn't bring the guest a cup of tea or anything-and my friend asked me, "Is that your mother-in-law?" I said to myself, "OK, this is enough. I can't bear this anymore."

Mrs. Chu found it much easier to request deferential performance from foreign maids in comparison with local obasans. Another employer, Mr. Tang, a 60-year-old retired small business owner, explained why there was such a difference:

Because we have different nationalities-she's a foreigner. A Taiwanese maid, although she's a maid, she is Taiwanese. I am Taiwanese. We grew up in the same place, so the distinction is not that clear. We somehow treat her with more courtesy. But the Filipina maid is different. She's Filipino, not Chinese.

When hiring a compatriot domestic worker who is "one of us," employers feel somehow obliged to view her as equal and treat her with respect despite the existence of class hierarchy. By contrast, the "foreignness" of migrant domestics seems to justify discriminatory treatment of them. The employers characterize foreign workers as possessing "undesirable differences," such as laziness and a lack of work ethic, in opposition to the imagined ethnic traits of diligence and perseverance shared by both Taiwanese employers and workers (Cheng 2003:180). In addition to the nationality-based discourse of ethnic exclusion, the temporary and marginal status of weilao is institutionally endorsed by the state policy that excludes migrant workers from membership in the political community (citizenship and permanent residence).

Mrs. Chu also noticed a better protection of her family's privacy and social reputation after she replaced local domestic workers with Filipina workers:

It's easier to protect family privacy when you hire a Filipina maid. If you hire a Taiwanese, she knows the language and your neighborhood. She can gossip about your family! If you are a celebrity, your reputation can be ruined by her! Some even sell the news to tabloids! You don't have this kind of problem with Filipina maids. Whatever you talk about, she can't understand anyway.

In comparison with Taiwanese obasans, migrant workers are less of an intrusion into the employers' family life, because of their unfamiliarity with local language or network associations. Taiwanese employers are able to sustain a hierarchical distance from migrant workers given the workers' isolation from the host society and culture. Some characteristics of upperclass employers also facilitate the pattern of distant hierarchy. These employers usually have longer experiences of hiring domestic workers and have thus embodied class "habitus" (Bourdieu 1977), such as carrying more condescending verbal expressions and distant body language toward the workers. And these households often have a spacious residence that allows sufficient physical space, as well as social distance, to exist between workers and employers.

\section{Maternalism: "I Am Her Custodian in Taiwan"}

Barrie Thorne studied how boys and girls play at school and insightfully commented, "Boundaries can be created through contact as well as avoidance" (1993:64, my emphasis). Similarly, domestic employers can mark status distinctions by either avoiding or enhancing personal 
contacts with domestic workers. In contrast to a distant hierarchy, employers may develop an intimate relationship of maternal benevolence with domestic workers to affirm their own class and ethnic superiority. Maternalistic practices, as Mary Romero (1992:110) phrased it, define workers as needy, immature, and inadequate to master their own lives, while strengthening the employers' perceptions of themselves as generous, thoughtful, and superior moral guardians.

In particular, migrant domestic workers, as outsiders in the host country, serve as inferior protégés and risk-free confidants for their employers. Mrs. Lai is a 41 -year-old single mother who hired a Filipina worker, Julie, to help with housework and care for her aging mother-inlaw. Julie had once run away to MECO (the Manila Economic Cultural Office in Taipei), ${ }^{10}$ complaining that Mrs. Lai had restricted her activities and deprived her of her right to take days off. Mrs. Lai was furious and defended herself by saying that she was actually a "good employer." She explained to me why she had to watch out for Julie, who was only four years younger than she:

Last time she said she wanted to go to visit a friend in Yi-Lan. I said no. I couldn't let her go out by herself. I am her custodian in Taiwan. If something happens, how can I face her parents? The employment agency told us we shouldn't lend her money, but I still did. When she went home for vacation, we bought her a lot of clothes and gifts . . . Yes, I don't let her off on Sundays. That's because I'm afraid she might make some bad friends in the church. We're also concerned that she might be bored, so we bring her along whenever we go to dinner or shopping.

Taiwanese employers like Mrs. Lai view themselves as surrogate mothers or custodians of their foreign maids, thus claiming a necessity of intervening in their maids' private lives. These employers arrange travel plans for a worker's vacation, withhold the worker's passport, request details of the worker's social activities, and withhold a portion of wages as "forced saving" or "compulsory deposit." ${ }^{11}$ This measure, despite being euphemized as a well-intentioned one, implies a racist stereotype about Southeast Asians- “They don't know how to save money" an employer said. In the eyes of these employers, the laziness and backwardness of weilao explain why their countries have not achieved industrialization or modernization as successfully as Taiwan has, or, at least, these qualities are unavoidable consequences given the underdevelopment of their countries.

Although portrayed by employers as "protection," these actions work as a form of labor control. In fact, employers deduct forced savings to discourage migrant workers from running away, and the "no-day-off" policy aims to obstruct workers from building local connections with NGOs and other migrant workers. While depriving workers of their rest days, many employers also patronize the workers by decreasing their workload on Sundays or by taking them along on family outings and dinners. For example, Peggy and her friend, who also employs a domestic worker, take their Filipina employees to movies every other month. The employers drive the workers to the theater, pay for their tickets, and pick them up right after the movie finishes.

Another way in which some employers intrude on workers' privacy is by intentionally disclosing their personal lives to them. For example, Jovita, a Filipina worker in her late 20s, described her homemaker employer as follows.

Jovita: She talks to me a lot, maybe because she doesn't trust her friends. At least I won't talk to any of her friends. She often complains to me about her husband. She told me they never make love anymore! Yeah, we Filipinas know all the secrets in the family.

10. MECO is the de facto Philippine embassy in Taiwan, because there is no formal diplomatic tie between the two countries.

11. The deduction ranges between NT\$3,000-5,000, equivalent to one-fifth to one-third of a worker's monthly wage, NT\$15,840. The money will not be returned to the worker until she completes the contract and leaves Taiwan. 
PCL: So you two have a close relationship?

Jovita: Yes and no. She is a good actress, and I am, too! Maybe when she talks to her friend who also has a Filipina, they are chochochocho [talking] about me. But it's OK. I talk to my Filipina friends, too. I'm very talkative. That's why she likes me. She can only talk to her Filipina in the house. She's lonely.

This kind of voluntary confession is most common among female homemakers, who request the attentive ears of their "home sisters" to ease their own isolation and loneliness. Their secrets are especially safe with migrant domestic workers. Compared to local workers who may gossip, migrant workers are "trustworthy" confidants because they are temporary in Taiwanese society and totally excluded from the employer's social circles.

As Rollins (1985) and many others have documented, benevolent maternalism is most clearly illustrated by "gift-giving"-employers give away second-hand or discarded items, especially old clothes, as "gifts" to domestic workers. Some Taiwanese employers also bring home the leftovers for their domestic workers after a meal at a restaurant. Although the employers perceive this as a well-intended gesture, most Filipina workers view it as a means of humiliation. Trinada, a real estate agent in the Philippines and a maid in Taiwan, explained, "Some employers go out for dinner and buy leftovers. You ask them why and they said I have a Filipina. That's not good. I don't eat leftovers. I feel disgraced. We are not rich, but we don't eat leftovers." Another Filipina, Fela, described how she responded to being given leftovers:

Fela: Some employers give you food [from] three days ago. Who am I? I am not a dog. I am not going to eat food [from] three days ago.

PCL: Then what did you do with it?

Fela: I throw it away, and I buy my own food and I cook my own food. Then she can see what I am doing.

PCL: Did you say anything to them?

Fela: No, I didn't say anything to the employer. I didn't want to argue.

When given used clothes or leftovers from their employers, domestic workers are expected to respond with an appropriate performance of "no return." However, employers may request to have these "gifts" returned, as Jovita described:

Jovita: All my clothes are from her. She bought so many things, all expensive. Then she threw them away in a bag. She said I could try [them on]. If I like it I can keep it, or give it to other people. Sometimes when she sees me wearing her clothes, she said, "I don't know why I threw that out, it still looks nice." Then I said, "Well, you can have it back."

PCL: Did she ever take it back?

Jovita: Sometimes. Once she said, "Do you still have the bag I threw away last time? Can I borrow it just once? Because it fits my clothes tonight." I laughed in my heart and said, "Sure, they were yours anyway."

This example reveals an asymmetrical power relationship behind this practice of "giftgiving." The recipient (worker) is not allowed to return the gift, but the gift-giver (employer) may request a return from the recipient and reclaim her ownership of the gift. The employer can selectively confide her secrets to the worker and even request the details of the worker's social life, but the worker cannot freely refuse the confession or questions. Although maternalistic employers liken employment relations to family ties, domestic workers are nevertheless accorded marginal and subordinate status in the family.

So far I have established the ideal types of distant hierarchy and maternalism, but I would like to emphasize that employers may combine and interchange these two approaches depending on the context. In Taiwan, eating arrangements often vary as a result of the presence of various family members. When there are only women and children at home, the domestic worker is allowed to eat at the same table, or sit in the living room to watch television with the family. However, the worker is excluded when male employers or senior family members sit at the table. In other words, family boundaries are composed of concentric circles 
in parallel with status hierarchies among family members. The inclusion or exclusion of domestic workers becomes a marker for the composition of multi-layered family boundaries.

\section{Personalism: "I Don't Want to Live in a Status Hierarchy"}

Not all Taiwanese employers enjoy an overt display of their privileged social status. A substantial proportion of them, mostly middle class of younger generations, feels uncomfortable, uneasy, or even guilty about the status hierarchies between themselves and their foreign employees. Guo-Ming is a 35-year-old graphic designer; he runs a studio together with his wife, also a graphic designer. They are so occupied by work that they sometimes sleep in the office, leaving their two daughters to the care of the Filipina worker. Guo-Min identifies his family as an "average middle-class family" who just make ends meet after paying off housing loans and saving for the educational expenses of their children. Although this Filipina worker has been a great help in the family, Guo-Ming feels quite uncomfortable with a relationship of distant hierarchy:

GM: She [the Filipina worker] has been with us for a couple of years, but she's still very reserved, overcautious.

PCL: Could you be more specific? Like what kinds of situations?

GM: Um, for example, she never initiates a conversation with us unless we ask her something, and she always answers very briefly. We want her to sit at table to have dinner with us, but she'd rather eat after we are done. I am really not used to that, but if we ask her to eat with us, she actually feels very uneasy. Then we look at her, we feel uneasy ourselves, too. I keep wondering why she wants to keep some distance from us ... I don't like the feeling of living in a class hierarchy. This is very different from eating in a restaurant. I don't know why, but being served by a waiter or waitress is much more OK.

PCL: Why different? Because this is at home?

GM: Yeah, home is a very private setting, not a public space. So when your home becomes something like a restaurant, doesn't this make you nervous?

Guo-Ming does not feel flattered, but bothered by the deferential treatment of the Filipina worker, such as her way of communicating (never initiating conversations) and her eating preferences (eating after the family is finished). The liberal guilt of middle-class employers is magnified when a status hierarchy is located at home. According to Guo-Ming, home, defined as a private haven, should be distinct from a public restaurant, which has a more "natural" association with depersonalized bureaucracy.

Another employer who shares similar feelings is Wen-Jen, a college professor and a mother of two in her late 30s. She considers the deferential verbal and body language of her Filipina employee not as a status marker, but as a psychological burden:

WJ: I think it is Filipina maids themselves who act like that. I never request that. Actually it's more difficult for me to get along with them when they are acting like that, like they want to serve you. Many things, I just want to do them myself.

PCL: Like what?

WJ: For example, when I am cooking, to move the food in the pan to a plate, that's no big deal. But she thinks that's something she should do, if you don't let her do it, she becomes really nervous. Or when we are talking, she would say, "Your family is rich, mine is poor, I envy you."

Middle-class employers like Wen-Jen want to dissociate themselves from the feudal tradition of domestic servitude. They downplay the social distance between themselves and the domestic workers as a way of validating their middle-class identity-an identity associated with the values of self-reliance, equality, and democracy in a modernized society (Lan 2003). They also try to establish personal ties with their domestic workers so that they can ease the discomfort they feel at having workers live in their home, i.e., turning their private haven into a workplace. Many replace the derogatory title of "maid" with terms they perceive as status-neutral, such as "babysitter," "caregiver," and "helper." Some even analogize domestic 
workers as family members, calling them "sister" or "auntie." They ask the domestic workers to sit at the table with the family while having meals or invite them to join family outings. They welcome the workers into the living room to watch television together with the family, and they seek conversations about the worker's personal background and family life.

Another reason for employers to foster personal relationships with migrant domestic workers is the involvement of care work. Employers cultivate a relationship of "instrumental personalism" or "strategic intimacy" (Hondagneu-Sotelo 2001) to ensure good care for their children. Melissa is a 36-year-old business manager and a mother of two. She hires a Filipina caretaker, Neda, who has three children around the same ages as Melissa's children. Melissa detected some feelings of envy or deprivation on Neda's side, concerning the disparity of material living conditions of Neda's children in the Philippines and those of Melissa's family in Taiwan. Melissa observed:

Sometimes I feel kind of sorry for her. Because here we enjoy better economic conditions, whatever the children want, we can easily satisfy them. But it's not the same for her children . . . Sometimes when I buy stuff for my children, she has an envious look on her face.

Melissa spends time chatting with Neda in an attempt to comfort her homesickness while she is separated from her own children. Melissa bluntly admits that such emotional engagement is a strategic act solely for the benefit of her children: "Everything I do for her [Neda] is for my children." Parents like Melissa engage in emotional work to ensure that no unusual problems are happening in the lives of caretakers they hire. They also use family inclusion as a strategy to ensure the quality of care offered by their domestic workers. Fictive family membership can enhance a worker's commitment to the welfare of her employers, as well as the authenticity and sincerity of their emotional labor, their "labor of love."

The above discussion has revealed a practice of personalism/family inclusion that is similar yet distinct from maternalism. According to Hondagneu-Sotelo (2001:207-8), personalism is a two-way relationship, albeit still asymmetrical, that recognizes the worker's human dignity, in contrast to maternalism, a one-way relationship defined only by the employer's gestures of charity. She points out that employers personalize relationships with their domestic workers not to enhance a status hierarchy but to secure good care for their children. I have further established that employers also adopt the attitude of personalism to minimize their class guilt, to confirm their middle-class identity, and to ease the discomfort of a conflation of private and public spheres.

The distinction between personalism and maternalism is yet a fine line, given the inherent status hierarchies in the employment of foreign domestics. Personalism may be a cure for the loneliness of a migrant worker, but many workers would rather maintain some distance from their employers-who may be caring friends at this moment but turn into condescending madams in the next. Filipina domestic workers do not always favor personalism, and neither do Taiwanese employers. Melissa explained, "My husband often complains, 'We don't even have time to take care of our children. Now we have to take care of her?'" She then sighed deeply and remarked, "We hire her to help, but actually, she brings us more trouble than help!" Given the time crunch of dual-earner households, many employers view the personalistic aspects of employment as a time-consuming burden. Some employers thus confine the employment relationship within business terms, especially those who hire migrant workers for the purpose of housework instead of care work.

\section{Business Only: "I Need a Helper, Not a Friend"}

I met Jessica for lunch at the café in the shiny, high-rise building where she worked. At the age of 32, Jessica has worked in several international banks and has been promoted to the position of manager in her current job. Arriving in a no-nonsense black pantsuit, she told me that she had precisely one hour for the interview. Then, she quickly ordered a sandwich 
and organic fruit juice and started talking about her principle of interacting with her Filipina employee. She mentioned a friend of hers who is a full-time homemaker and married to a CEO. This friend also employed a domestic worker and killed many boring afternoons by having tea with the Filipina worker. Later they had a big fight over the issue of lending money and in the end, the worker was sent back home. Jessica commented on this story in Chinese spiced with English keywords (as indicated in italics):

I think you have to define her position clearly. You need a helper, not a friend. So you better not have tea or intimate conversation with her. Because once you two talk about things and she has different opinions from yours, then what? You try to dominate the conversation with your identity as a master! It's not fair. So I don't treat them like friends. Otherwise, either you will be over the line, or she will be over the line. Maybe one day she will talk to you in a way like, "Hey Jessica, I am too tired today. I don't want to cook!" . . The rule is clear in our house. After a certain time, it's her time off. I told my son not to bother her during her rest time.

Jessica prefers a business-like relationship for two reasons. First, recognizing status disparity between employers and employees, she defines the relationship as business-bound with a respect for the worker's private space and rest time. Second, minimizing personal interactions helps her clarify the worker's position (as "helper" rather than "friend") so as to avoid the interference of personal ties with job performance. Employers like Jessica are confident in their English communication with Filipina workers, and they tend to apply their working experiences as managers to the supervision of domestic workers. Another employer, Pei-Chi, is in her mid-40s and the owner of a family-run computer business. Sitting in her spacious office, she explained to me the difference between her kind of employers and others:

Pei-Chi: Most of my friends have positive employment experiences, probably because most of us work in the computer industry and we all know how to speak English. Those who have negative experiences are less educated people.

PCL: Why is there such a difference?

Pei-Chi: Because they don't know how to speak English and they don't know how to establish rules! Not like us. We set up clear rules and nothing would go wrong. So I say, it's the fault of the employers.

Pei-Chi went on to illustrate how she set up rational rules to manage the performance of her Filipina employee:

The moment she arrived, I typed up a chart that listed all the chores, what to do from this time to that time. Clean this on Monday, clean that on Tuesday. Daily schedule, weekly schedule, monthly schedule, very clear. In this way, the Filipina maid has a clear idea about her job content. When she is done with it, she can rest and I can know what she has done at home, too. One Filipina asked me if she could decide what to do each day. She said she must have more to do than the chart. I said, "No need. You just treat this like going to work. Once you are done, you are off."

Both Pei-Chi and Jessica explicitly used the metaphors "going to work" and "time off" to describe their households as a workplace. As long as these bureaucratic rules are followed, they make no further requests on the workers and avoid interference in the workers' private lives. Although there is a spatial overlap between workplace and home, these employers manage to draw a symbolic line between the public and private zones. This pattern not only protects the privacy of workers but also safeguards the family lives of employers. Earlier, I have mentioned that upper-class employers prefer migrant domestics because ethnic stratification helps sustain class domination. In a similar yet distinct way, middle-class employers report that it is easier to maintain a business-like relationship with foreign domestics compared to Taiwanese obasans. Employers can easily shut their family lives from migrant workers via linguistic and cultural barriers, but it is difficult to prevent local workers from intruding on the employers' private lives. Ann, a 32-year-old stockbroker and a mother of two, described the difference: 
Ann: Our neighbors hire an obasan. She minds their family business as she were their mother! A Filipina maid is different. She won't mind any of your business. I think this is much better.

PCL: Why is there a difference like this?

Ann: The first reason is communication. Second, Chinese think if I am hired by your family, I help with everything in the family. But a Filipina maid just comes here for work. If you don't talk to her, she won't come to you. I prefer this way. When we go home after work, we are exhausted enough. Nobody wants to hear another person blah blah blah.

Most local domestic workers are middle-aged women (the term obasan originally refers to senior women in Japanese). Younger employers like Ann sometimes feel pressure from obasans, who may exercise authority on the basis of seniority to dictate how housework or childcare should be done. Ann even likens the role of obasans to that of her mother or motherin-law. She therefore prefers migrant domestic workers who respect or desire a business-only relationship as much as she does.

The employers who prefer a business-oriented relationship are mostly from doubleincome households. Time deficit is serious enough for them-they seek helping hands specifically to loosen the time bind between work and family (Hochschild 1997). Hence they wish to maximize their free time after work by minimizing personal interactions with their domestic workers. Besides, a distant yet neutral relationship is more feasible in households where the employers spend only limited time at home, compared to households where full-time homemaker employers spend the whole day around workers. Employers also feel more comfortable setting up bureaucratic work rules when more housework and less care work is involved in the job.

In addition to the time constraint, the spatial setting also has a substantial impact on the ways employers negotiate their private zones. Unlike upper-class families who own spacious houses, most middle-class Taiwanese households in urban areas can afford only modest apartments. Facing the problem of spatial deficit, some employers exclude domestic workers from home space not (just) to demonstrate spatial deference, but to protect their family's privacy. In other cases, the employers have no option but to maintain an inclusive relationship with the workers because of the limited space at home. Susan works for a marketing company; she and her husband have recently purchased their first apartment in Taipei. When I asked her about the eating arrangements with her domestic worker, she laughed at my question, saying, "Look at my apartment! It's so tiny. If she doesn't eat with us, where is she going to eat?"

I have emphasized that these typological categories are not mutually exclusive, but that they are ideal-typical polarities of continuums in reality. Most employers attempt to achieve a balance between a trustworthy personal relationship and a hassle-free business relationship. For example, eating arrangements often change by context. Some domestic workers are invited to eat with the family at a regular time, but they are requested to eat separately when there are guests. One employer, Jack, explained his situational definition of "family member" saying, "We always bring her when we go out, like a family. But in front of outsiders, the distinction has to be clear. It's a matter of discipline." Similar to the employers who swing between the approaches of distant hierarchy and maternalism, middle-class employers sculpt family boundaries as multiple layers. They include the domestic workers in their families to a limited degree and in particular circumstances, so that they can give consideration to safeguarding family privacy, maintaining adequate social distance, and securing trust in their foreign employees.

\section{Workers' Boundary Work}

When the private home becomes a workplace, employers construct multi-layered family boundaries to fence their privacy. By contrast, migrant live-in domestic workers enhance their privacy by reorganizing public and private spaces in their lives. They live a dual life that 
can be described by Erving Goffman's (1959) metaphors of "front" and "backstage." During the week, domestic workers "act like maids" in front of the audience, their employers. Yet, on Sundays, the most common rest day for migrant workers in Taiwan, they display a distinct "offstage" identity beyond the direct observation of their employers. This "backstage" region is situated in public space, which ironically provides migrant workers with more freedom and privacy.

Filipina domestic workers usually spend their Sundays in the following routine: In the morning they gather with their compatriots at church and attend mass. Afterwards they go shopping, have lunch, or get a haircut in the neighborhood around the church. They are also found in nearby parks and tourist spots, having picnics and taking photos. A few disco clubs target Filipino migrants as major customers on Sunday afternoons. Some even provide free shuttles to transport migrant workers from the church to the clubs. And they hang out in fast food restaurants or Taipei's main train station until their curfew, usually between seven and nine o' clock in the evening.

The workers' "backstage" activities on Sunday constitute a dramatic contrast to their performance at work. On weekdays, they display subservience and pretend to be stupid. On Sundays, they exchange funny stories and jokes that often mock their employers' manners, tastes, or English mistakes. In the employers' houses, domestic workers lack the autonomy to cook the kinds of food they like; some even suffer from hunger or humiliation owning to the limited portions or variety of food they are given by their employers. Sunday, by contrast, is a feast day for migrant workers with generous amounts of ethnic food. Although domestic workers cannot refuse used items handed down from employers on the front stage, shopping becomes a way for them to feel "empowered" backstage. Many workers spend a substantial amount of time and money shopping for a variety of items including clothing, jewelry, and cellular phones.

Off-day dressing vividly symbolizes the shifting identities between the front and backstage areas. In the employers' domains, migrant domestic workers are prohibited from wearing make-up, jewelry, nail polish, or perfume; their dress codes, following the "simple and clean" principle, display the workers' inferior status and suppress their femininity, which might threaten their madams. When going out on Sundays, they dress up in blouses, brand-name jeans, or short skirts, and put on makeup, nail polish, and dangling gold earrings. With these material markers, they project an urban, fashion-conscious, sophisticated, and feminine image (Constable 1997b). ${ }^{12}$

Like their Taiwanese employers, Filipina domestics construct and maintain social boundaries in various ways. Two major concerns characterize their boundary work. The first is about how workers perceive and respond to the social distance between themselves and their employers: some recognize and accept the apparent class and ethnic divides, but others object to the divides and identify themselves as equal human beings and class peers of their employers. The second concern is about the deployment of the front and backstage areas in their lives: some workers prefer to segment these two areas, but others prefer to integrate them. ${ }^{13}$ Based on these two dimensions, I generate four categories of boundary work enacted by domestic workers: seeking patronage, keeping safe distance, obscuring previous positions, and highlighting status similarity (see Figure 2 ).

\section{Seeking Patronage: "Poor Girls Always Get Lucky"}

Jenny and Maya sat with me on a bench in the churchyard, chatting about their employers. Both of them, now in their mid-thirties, were factory workers in the Philippines

12. The construct of the front/backstage areas is relatively defined. If we consider the presence of migrant fellows as the audience, Sunday activities constitute a front area in which migrant domestics perform a non-maid role.

13. The characteristics of "segmenting" and "integrating" are inspired by Christena Nippert-Eng (1995), who discusses how office workers negotiate the boundary between home and work. 


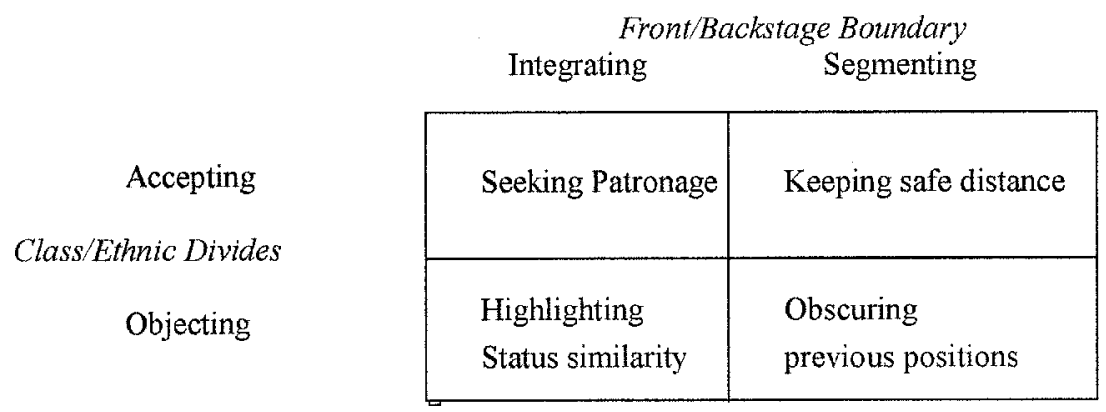

Figure 2 • Typology of Domestic Workers' Boundary Work

and have worked in Singapore and Taiwan as domestic workers for several years. "Poor girls always get lucky," said Jenny, commenting on Maya's strategies toward her employer. Maya first came to Taiwan five years ago. After this contract expired, she changed her name and returned here to a new employer (the maximum for a legal stay was three years then). She gladly told me that she was able to avoid the "forced savings" (wage deduction) after crying and pleading with her employer, saying, "Please help me. I have no money. I owe a lot of money at home."

Workers like Maya are engaged in what Jennifer Mendez (1998:129) calls "strategic personalism," through which they obtain alternative "fringe benefits" from their employers in the form of material goods, cash bonuses, and loans. Other researchers have also reported that domestic workers often artfully utilize emotional displays to win over employers' sympathy (Parrenas 2001), or they strategically elicit the class guilt of their employers to generate favors and raises (Ozyegin 2001).

A quasi-feudal pattern of the patron-client relationship is not prevalent among the Taiwanese households who hire migrant workers; this is mainly due to the condition that migrant workers may only be employed for a short period under government regulations. Still, some Filipina migrant workers, usually those with less education or from the rural areas, consciously play up their own material poverty to win their employers' sympathy. In particular, those who have previously worked overseas as domestics are better at maneuvering "strategic personalism." Some talk to the employers about their meager living conditions in the Philippines, so they will have a better chance of success when requesting loans or advances on their wages. Some also display envy when their employers purchase expensive toys for their children. Out of feelings of guilt or sympathy, the employer might buy another toy (oftentimes a cheaper one) for the worker's children.

Newly arrived migrant workers are another group who tend to seek patronage from their employers. During their first year, most migrant workers are burdened by debts and they receive only a small amount of wages after the deduction of placement fees. In these circumstances, they welcome second-hand items from the employers as some sort of "payment in kind." During the first few months, migrant workers usually give up their days off because they have little money at their disposal and they want to earn extra wages. Joining the employers' family outings becomes a cost-free opportunity for them to explore Taiwan. They also have to rely on employers for a variety of information and resources, since they have yet to build up local connections in the host country.

Some migrant domestic workers foster personal ties with their employers not to extract material benefits, but to seek emotional rewards. This mostly happens to workers who are 
employed to take care of elders or young children. Angelina is a mother of two in her late 30s. Before going abroad, she worked in the fields with her husband in the Philippines. Her job in Taiwan is taking care of a 60-year-old infirm woman who lives with two single daughters. Angelina likes to integrate herself into her employers' family, transforming her labor from a form of commodified "work" into a "labor of love":

Angelina: They treat me like their family. They want me to call her Amah ["grandmother" in Taiwanese], not Madam.

PCL: $\quad$ What's the difference?

Angelina: Amah is closer. It's like you are one of the family. Every Sunday, my employer told me Amah doesn't like me to go out: "She does not eat if you go out."

Vanessa: [another Filipina domestic worker] They are selfish! This is your rest day!

Angelina: No, they are not selfish. I feel happy about it, because I know they love me. They care about me. Amah treats me like her family.

Vanessa: You should take it! [the overtime pay] That's money!

Angelina: [shakes her head with a serious look on her face] Because their goodness to me goes beyond that amount of overtime pay. I feel like part of the family, so I don't want to take their money.

The choice to integrate oneself into an employer's family can be a double-edged sword for domestic workers. On the one hand, workers can use their bonds with the care recipients to advance their status in the family and to exchange for material or emotional rewards from employers. On the other hand, the idea that they are part of the family may disadvantage workers by obscuring contract-bound employment relations. Employers might manipulate a worker's emotional attachment to her ward in order to extract additional unpaid labor or to request overtime. Another Filipina caretaker, Sylvia, takes care of an elder living alone. Sylvia has forfeited her annual one-week vacation (specified in her contract) twice in the last two years, losing the chance to visit her three children, who are cared for by her mother in the Philippines. Sylvia told me:

My son always says, "Mom, when are you coming back to the Philippines?" I keep saying, "Maybe next year, maybe." I will be three years this June, but they don't want me to take a vacation. Nobody can take care of her if I am not here.

Care workers like Angelina and Sylvia are "adopted" by their employers as their "fictive kin," a term which refers to "those who provide care like family and do what family does [and] are given the labor of kin with its attendant affection, rights, and obligations" (Karner 1998:70). They are, however, allocated a peripheral status in the family. To fulfill their commitment to the fictive family of their care recipients, migrant care workers bear the costs of separating from their own family in their home countries.

\section{Keeping Distance: "No Extracurricular Work"}

During lunch, one Filipina spoke about her previous experience working in Saudi Arabia, where she had meals with several other domestic workers in the servants' quarter. "Wow, that's great," said Olivia, another domestic worker at the table, upon hearing this. I was surprised at her envy of this spatial segregation that displays a transparent class hierarchy. Olivia explained to me, "It's safer to keep some distance." In fact, Olivia is not alone in holding such a preference. Many migrant domestics do not crave personal bonds with their employers but prefer to keep some distance from them. I heard many conversations among Filipina workers similar to this one:

Johna [sobbing]: My lady employer has a bad attitude toward me.

PCL: $\quad$ Like how?

Johna: $\quad$ You can see it from her face ... 
Madeline: Don't look at their faces! Just listen to your own heart! They and us are different [uses her two hands to indicate high and low levels]. They just act like that. Don't mind them.

Sylvia: Yes! Because they and us are different status, sometimes they don't know [that] what they did hurt us. As long as you know you do good, and they pay your check on time, no extracurricular work! [Everybody nods, especially Johna]

"No extracurricular work" is a common strategy employed by Filipina domestic workers to cope with their physical and emotional stress at work. When they establish a boundary between work and private life, this kind of detachment provides them with a buffer against the employer's insensitivity to their personal needs and dignity (Dill 1988:39). They also prefer to minimize interactions with their employers so they can reduce the burden of extra emotional work. When asked if they enjoy going out to dinner with their employers, many informants answered, "No, I'd rather stay home. I don't want to be a babysitter at the dining table. I want to be a family." Despite the family analogy used by their employers, most migrant domestic workers are keenly aware of their marginal status. Keeping a distance from the employers' family allows them to avoid the risk of transgressing the line between family and non-family.

Although some Filipina workers like to join the employers' family meals, others consider eating together an extra pressure and obligation. Many domestic workers would rather eat alone in the kitchen-a backstage region where they can have more privacy and freedom. When I asked Helen if she eats together with her employer, she answered, "They told me to. Sometimes their friends coming, they told me to eat together, too. But I don't like it. So I pretend busy, I do this I do that, because I don't want to eat together. Too tiring. What am I going to say to them?"

In addition, many domestic workers dislike the invitation to eat at the dining table because they feel obligated to accept food from their employers. Elvie described this situation saying, "My employers want me to eat this and eat that, so I don't like to eat there [at the table]. They want to see you eating the things. They want to give. They want to make sure you eat it." It is a common practice among Taiwanese that the host picks up a portion of food from the table and places it in the guest's bowl. This act, intended to be courteous, may turn into a coercive measure in the eyes of migrant domestics. In a situation similar to that of an asymmetrical act of gift-giving, the workers are afraid that their refusal of the food might offend the employers.

Another aspect of their jobs that domestic workers are reluctant about is being put in the position of the employers' confidant, especially when the secrets involve tensions between the employer couple. One single Filipina worker, Lolita, feels burdened by being sandwiched between the confidences of the wife and the husband:

My lady employer talks to me a lot, even her personal things, like her work, her family, her marriage, everything! She's not getting along with her mother-in-law, and her marriage isn't going well. She told me not to marry a husband like hers. And you know what's funny? The husband likes to talk to me about his wife, too! But they don't know [that] the other person also talks to me. If they knew, they wouldn't be very happy [about this]. But I don't want to hear these things. I came here for work, not for hearing this stuff.

When their male employers resort to them as confidants, migrant domestic workers even risk becoming a target of the suspicion or jealousy of the female employers. Some workers have discovered the extra-marital affairs of one of their employers, finding condoms in the husband's pocket while doing the laundry, or seeing the secret lover of the wife while the husband is away. Whether or not they report the matter to the other employer, they are unavoidably involved in the family drama. By managing to separate the front and backstage regions, domestic workers reduce the risks and burdens involved in a personalized relationship, and mark the boundary to lessen employers' intervention in their private lives. 


\section{Obscuring Previous Positions: "I Don't Want Them to Know My Past"}

Domestic workers may segment the front and backstage regions not just for the reason of being cautious, but as an active strategy to safeguard their dignity and self-identity. These migrant workers consider themselves to be class peers of their Taiwanese employers, viewing their downward mobility as only a consequence of personal misfortune or the stagnant economy of their home country. When I asked Luisa if her employer was rich, she bluntly answered, "I don't think so. They have a simple life. They don't go out. I know that, because I used to be rich." Luisa left Manila to work as an entertainer in Tokyo at the age of 21 . Later she married the Japanese owner of the club where she worked. Their marriage lasted ten years. After the divorce she returned to the Philippines with two children, and later worked in Taiwan as a domestic worker.

Having difficulty adjusting to her fall on the class ladder, Luisa chooses to disguise her current job from her acquaintances in the Philippines and to conceal her past from her employers in Taiwan:

Luisa: I didn't tell my friends in the Philippines what I am doing in Taiwan. They only know I work. They don't know I am a domestic helper. I feel ashamed. Because I used to be an employer, I don't want people to think I am going down. But actually I am going down [a bitter smile]. My ex-husband doesn't know [about this], either. He called my children, and they told him, mama is visiting relatives in Taiwan.

PCL: Does your employer know about your past?

Luisa: No. Once, my ex-husband called me from Japan. I just told them that was my brother-inlaw. I don't want them to know.

Luisa obscures her previous social positions in front of her employers. To perfect the "maid" performance, she has to carefully manage the transition from the front to the back stage. One Sunday I went out with Luisa and several other Filipinas for lunch after mass. As we were sitting in a fast food restaurant, I saw a bag with clothes in it and I asked Luisa if she had just been shopping. She shook her head and explained to me, with an embarrassed smile:

No, those are the clothes I have to change [into] when I go home. When I go out, I want to look smart, fashionable, and intelligent. In these clothes [points to clothes she is wearing] I'm like a business manager. Those clothes [points at bag] I bought in the market, for a hundred dollars [US\$3]! I look like a "floor manager" in those! [big laugh]. So, before I go home, I change, I take off my makeup, I change my mini skirt ... I look like a totally different person at home . . . Just like Cinderella [bitter smile].

Every Sunday, Luisa brings her jewelry, mini-skirt, and make-up kit to the church and changes in the bathroom before attending mass. She also tries to shy away from the identity of "maid" after she goes backstage. One Sunday, when we walked through the backyard of the church, where many Filipinas were chatting as usual, Luisa frowned and said, "They are talking about many problems here. My employer this, my employer that. I know it's good for you to listen. But I don't like to come here. I don't like to spend my holiday like this. Monday to Saturday is already enough. I don't want to hear more complaints about work. I just want to be happy, happy on Sunday!"

When moving from the backstage area to the front, migrant domestic workers try to present a version of their Sunday activities that is deemed "appropriate" in the eyes of their employers. A few times I went to discos with workers on Sunday afternoons. When we were about to leave, some Filipinas changed their shirts as they might have absorbed too much cigarette smoke on the dance floor. They responded to my confusion: "So our employers will think we go to the church! Not the disco!" Jovita, a single Filipina in her late 20s, told me that sometimes she spends Sunday afternoons in bars, drinking or smoking to relax. Upon her return to her employers' house, she said, "The first thing I do is to run into the bathroom first and take a shower. I don't want them to smell me!" 
By maintaining an impenetrable boundary between the front and backstage areas, domestic workers try to avert tension between the "maid" image prescribed by their employers and the day-off image that accords with their previous lifestyle. As Goffman (1959:113) remarks, "the passage from the front region to the back region will be kept closed to members of the audience or . . . the entire region will be kept hidden from them." If the worker fails to maintain segregation between these two social spaces, their off-stage image may shock their employers. Luisa's employer left home early one Sunday. Instead of carrying clothes to change into later, Luisa walked out of her employer's apartment wearing a silk blouse and with her hair dyed burgundy. She described what happened and how her employer responded to it:

Luisa: My neighbors in the elevator saw me [and] smelled my perfume. And there were rumors in the whole building! They told my employer: "Luisa goes out, like a movie star!" My boss didn't believe it. So the security guard rewound the videotape-they have a video in the elevator-and showed it to my employer.

PCL: How did your employer react?

Luisa: She was very surprised! Because I'm not like that on ordinary days. I think she felt insecure after that. She told me: "I don't have many beautiful dresses, because I don't need them. I am always in the house..."

PCL: What was she trying to say?

Luisa: She was saying that I don't need these dresses, because I am always in the house. I am just wasting my money!

Filipina domestic workers often compliment each other on Sundays by saying, "Wow, you look like our madams!" They use off-day dressing to subvert the hierarchical difference between "madam" and "maid" on the front stage. However, in Luisa's case, the exposure of her backstage image-a stylish, classy, and feminine image-constitutes a symbolic challenge to the class superiority of the employer, and more, stirs the madam's anxiety. As one Filipina interviewee commented, "She's afraid you become an attractive woman. Then she will lose her husband!" Luisa found it difficult or at least risky to merge the front and backstage areas, but other Filipina migrant workers weave their identities at work and in private to underscore the similarity between their own status and that of their employers.

\section{Highlighting Status Similarity: "I Don't Let Them Disgrace Me"}

Nora, single and in her early 30s, received a college degree in nursing in the Philippines. She first went to Singapore working as a nurse at the age of 24. In Taiwan, she is hired to take care of an ill grandmother living with a divorced father and his teenage son. The father is a technician with a high school diploma. In the beginning, Nora felt quite offended when her employers expressed doubts about her knowledge of modern lifestyle. "Taiwanese employers think Filipinos are ignorant," she said. "They asked me, 'Do you know how to turn on the television? How to use a rice cooker?'" Nora responded to her employers with a firm answer: "I said to them, 'No problem for me.'" Her employers have gradually changed their opinions about her, which has a lot to do with the fact that Nora has a higher degree than anyone in the family. Nora told me:

They are proud. They told people I went to college. My boss doesn't say, "This is my maid." They say, "This is the one who takes good care of my mother." If they call me a maid, I will feel a little upset. Because people have ego, you want to go up, not go down.

Nora then raised examples of how her education has equipped her with the ability to reason with her employers, unlike other Filipinas who only whine about them:

Many Filipinos complain about their employers. They should talk to them. If there is a problem, I don't complain. I talk to them. Once there were five Sundays in that month, they gave me only four [for overtime pay]. I told them there were five Sundays. Then they said, "Oh, you are right." 
Migrant domestic workers who held managerial positions in the Philippines may define domestic service as skilled work and underscore its similarity to their previous working experience. Shu-Ju Ada Cheng (2001) interviewed a Filipina domestic worker in Taiwan, Baby, who had a master's degree in accounting and business administration. Like Nora, Baby is not shy about telling her employers about her education; she maintains a sense of integrity by highlighting the professional aspect of domestic service:

It is work, and I use professional attitude for it . . I used to handle everything for my boss, taking notes and keeping track of everything. I am very alert. I keep track of everything. This is not that much difference. It's the same thing working here ... I have my own program of work, like when to do what, and which to do first throughout the whole day. I do planning. (Qtd. in Cheng 2001:202)

These cases demonstrate another way for Filipina domestic workers to merge the front and backstage regions-to establish their status as class peers of their employers. Two structural factors explain why Nora could attain a more equal status in this employment relationship. First, her main duty is taking care of a patient rather than household chores. Employers, as noted earlier, are more willing to cultivate a personal relationship with workers when care work is involved in their duty. Second, Nora possesses a higher degree of education and more linguistic capital than her employers-she even sometimes tutors the teenage son in English. Blue-collar employers perceive hiring a Filipina college graduate as a means of upgrading their own social status. That explains why they are "proud" to have Nora take care of their mother.

Trinada is another Filipina caretaker who falls into this category. She is a 44-year-old widow who had a successful career as a real estate agent in the Philippines. Motivated by a curiosity about the experience of working overseas, she came to work in Taiwan two years ago. The household of her employers includes a 65-year-old ill mother, her son, daughter-in-law, and two adult grandchildren. When I asked her about her employers, she shrugged and said:

They're OK. The only problem is they don't trust you. For example, if you go home late, they think you do bad things. They said, "Maybe you have bad friends." I said, "Don't say that! You never met my friends. If you say this to me, I can also say, you come home late sometimes, I can conclude you also do bad things outside!" If you always obey, you never get freedom. You cannot always agree with your employer, or they will treat you like this all the time. My employers treat me with respect. They say she is the one looking after our mother, not a domestic helper.

Trinada confronted her employers, who had made a racist assumption about migrant workers, by resorting to the principles of equality and mutuality-if you say this to me, I can say the same thing about you, too. Trinada and her employers have developed a relatively equal relationship indicated by the way they refer to each other. "They call me mei-meithat's younger sister, right?" she said. "And I call them their first names. They treat me like their younger sister, not a maid." Trinada also intentionally sends out messages to her employers regarding her equivalent lifestyle in the Philippines. "When we go to expensive restaurants, I told them, when I worked in the Philippines I went to similar restaurants, too. So they don't look down on me. I don't let them." Better-educated migrant domestic workers sometimes deliberately initiate conversations with their employers to showcase their cultural taste and knowledge (Hondagneu-Sotelo 2001:199). Several Taiwanese employers report feeling shocked, yet impressed, when they arrive home to find the Filipina maids watching CNN on television or listening to classical music on the radio.

English is another means that Trinada uses to level the power dynamics in the relationship with her employers. ${ }^{14}$ "If what they said is wrong, I told them this is wrong. They ask me about their English, 'Do I say this correctly?' I don't let them disgrace me. I always check. If

14. See Lan (2003) for more discussion about how the English language mediates the symbolic domination and resistance between Taiwanese employers and Filipina domestics. 
they say something bad, I always correct." When I asked her if she was ever afraid that her employers might get offended and terminate her contract, she said with total confidence, "No! I am not afraid to lose my job. My salary in the Philippines is even higher! I told them this!"

Unlike Luisa, who conceals her background from her employers, Trinada showcases her middle-class position and lifestyle in the Philippines to her employers. She confronts her employers' authority by challenging their English skills and rejecting their negative comments about migrant workers. She resists the deferential job script and speaks out to enhance her status in the family. As she said, "I don't let them disgrace me." Like Nora, Trinada has a certain capacity of negotiation because she is employed by a household of average wealth and her job is taking care of their mother.

How do we explain the distinct approaches to boundary work adopted by Luisa and Trinada, despite the fact that both perceive themselves as class peers of their employers? A major difference is related to the stakes involved in challenging employers and losing jobs. Trinada can afford the consequence of open confrontation, because she is "not afraid to lose the job." Being a mother of three grown-up children, she faces less financial pressure and she still keeps a career alternative in the Philippines. In contrast, Luisa, a single mother with three young children, cannot bear the consequence of losing the only financial source for her family. Therefore, she would rather not risk her job by integrating the front and backstage area.

The comparison also reveals another factor that limits domestic workers' options for their approach to boundary work. The way a worker negotiates the social distance from her employers must depend on the way her employers enact their own boundary work. Luisa might have preferred a more permeable boundary between her work and private life, if her employer had adopted a more inclusive, equal attitude toward her as Nora's or Trinada's employers do. Employers usually take initiative to define their relationship with domestic workers, leaving limited possibilities for the workers to negotiate social boundaries and private zones.

\section{Conclusion}

This article uses the theoretical lens of boundary work to examine the micropolitics of employing migrant domestic workers. I have mapped out how employers and workers identify their class positions vis-à-vis the other party, and have compared migrant and local domestic workers to highlight the significance of nationality-based ethnic distinctions in the employment dynamics. These personal encounters across social boundaries are nevertheless confined in a household that conflates the workplace and the private zone. Taiwanese employers, viewing themselves as superior patrons or liberal managers, are constructing multi-layered family boundaries to include as well as exclude their foreign employees, the intimate Other. Migrant domestic workers, the "diasporic homeless," resist the intrusion of privacy in employers' residences by turning public space into their private backstage areas.

With an emphasis on agency and diversity, my analysis of boundary work links actors' structural positions and subjective dispositions. I have established two typologies to describe variations in boundary work, and identified three major factors to account for why particular employers and workers lean toward a subtype of boundary work: the class positioning of employers and workers; the ratio of care work to housework in the job assignment; and the time-space composition of the employment setting. The employers who would like to showcase their advanced position in the class ladder tend to highlight their differences from the maids, while younger generations of employers try to confirm their middle-class identity by downplaying the class hierarchy. Among upper-class employers, those who spend less time at home and have more space in the house are more likely to maintain a distant hierarchy, whereas homemakers who spend a lot of time around the workers often develop a maternalistic relationship. Among middle-class employers, those who hire workers for childcare tend to adopt an 
attitude of instrumental personalism, while others who seek help with housework only favor a business-like relationship to minimize the time-consuming burden of personal interactions.

The above factors also shape variations in the boundary work of Filipina domestic workers. Those who view themselves as class peers of their employers usually prefer a permeable boundary between the front and backstage areas. Their attempt to seek equal status with their employers is more likely to be achieved when their primary job is related to care work. Other workers, despite privately contesting their employers' superiority, tend to obscure their previous social positions because a segmented approach can better protect their privacy and diminish the risk of confronting the employers' authority. Some workers, usually with less education or a blue-collar background, acknowledge the status difference between themselves and their employers. Among them, experienced migrants know how to manipulate personal ties for their own benefit, new migrants seek patronage from their employers to increase their resources, and those who are hired for care work desire family inclusion to gain emotional rewards. Other workers choose to minimize their interactions with employers so they can limit their exposure to extra emotional burdens and the risks of transgressing social boundaries. This approach is plausible especially when the workers are employed in a spacious house and when their employers work outside during the day.

Although I have presented these two typologies separately, boundary work conducted by employers and workers is nevertheless interactive. There is greater affinity in pairs of some categories and stronger opposition in other pairs. Patronage-seeking workers would appreciate favors given by maternalistic employers, while other workers find them humiliating or unwelcome. Personalism-oriented employers feel frustrated when their employees attempt to maintain a distance; these workers would match better with business-oriented employers or even distant employers. The employers who like to purchase deference would feel offended by the workers who challenge their superior status; it is more plausible for these workers to claim their status similarity to personalistic employers. However, because employers still have more power to prescribe the interactive scripts than workers, obscuring their previous positions is a less risky strategy for the workers burdened with the danger of being repatriated by their employers.

The employment of migrant domestic workers sheds light on identity politics in the context of global migration. An investigation of boundary work between employers and workers across borders reveals "the global in the local" (Dirlik 1996). It demonstrates the effects of territorial citizenship and racial stratification on everyday personal interactions. Migrant domestic workers are marginalized in host countries through politico-legal regulations and the cultural discourse of racism; their everyday interactions with host families are mediated by the construction of class distinctions, ethnic stratification, and spatial segregation. The local practice of boundary work in a household is a constituent part of reproducing structural inequalities in the global economy. Intimate interactions across ethnic and national divides have not stopped people from drawing distinctions between "us" and "them." More often, such encounters exacerbate the process of Otherization, when the privileged groups feel urged to fortify the social boundaries in the visible presence of outsiders. Globalization has indeed facilitated people's movements across borders, but boundary work proliferates to divide us in public as well as private domains.

\section{References}

Anderson, Bridget. 2000. Doing the Dirty Work? The Global Politics of Domestic Labour. London and New York: Zed Books.

Bourdieu, Pierre. 1977. Outline of a Theory of Practice. Oxford: Cambridge University Press. 
Chang, Grace. 2000. Disposable Domestics: Immigrant Women Workers in the Global Economy. Cambridge: South End Press.

Cheal, David. 1991. Family and the State of Theory. Toronto: University of Toronto Press.

Cheng, Shu-Ju Ada. 2001. Serving the Household and the Nation: Filipina Domestics and the Development of Nationhood in Taiwan. Ph.D. Dissertation, Department of Sociology, University of Texas, Austin, TX.

_ 2003. "Rethinking the Globilization of Domestic Service: Foreign Domestics, State Control, and the Politics of Identity in Taiwan." Gender and Society 17:166-86.

Colen, Shellee. 1986. "With Respect and Feelings: Voices of West Indian Child Care and Domestic Workers in New York City." Pp. 46-70 in All American Women: Lines that Divide, Ties that Bind, edited by J. B. Cole. Mankato, MN: The Free Press.

Constable, Nicole. 1997a. Maid to Order in Hong-Kong: Stories of Filipina Workers. Ithaca, NY: Cornell University Press.

_ 1997b. "Sexuality and Discipline among Filipina Domestic Workers in Hong Kong." American Ethnologist 24:539-58.

Council of Labor Affairs (CLA). 1999. The 1998 Investigation Report on the Management and Employment of Foreign Workers in R.O.C. Taipei: Executive Yuan, Republic of China.

- 2003. Monthly Bulletin of Labor Statistics, January 2003. Taipei: Executive Yuan, Republic of China.

Delphy, Christine and Diana Leonard. 1992. Familiar Exploitation: A New Analysis of Marriage in Contemporary Western Societies. Cambridge, U.K.: Polity Press.

DeVault, Marjorie. 1991. Feeding the Family: The Social Organization of Caring as Gendered Work. Chicago: The University of Chicago Press.

Dill, Bonnie Thornton. 1988. “Making Your Job Good Yourself: Domestic Service and the Construction of Personal Dignity." Pp. 33-52 in Women and the Politics of Empowerment, edited by A. Bookman and S. Morgan. Philadelphia: Temple University Press.

Dirlik, Arif. 1996. "The Global in the Local." Pp. 21-45 in Global/Local: Cultural Production and the Transnational Imaginary, edited by R. Wilson and W. Dissanayake. Durham, NC: Duke University Press.

Ehrenreich, Barbara and Arlie Russell Hochschild. 2002. Global Woman: Nannies, Maids, and Sex Workers in the New Economy. New York: Metropolitan Books.

Glenn, Evelyn Nakano. 1986. Issei, Nisei, War Bride: Three Generations of Japanese American Women in Domestic Service. Philadelphia: Temple University Press.

Goffman, Erving. 1956. "The Nature of Deference and Demeanor." American Anthropologist 58:473-502.

- 1959. The Presentation of Self in Everyday Life. Doubleday: Anchor Books.

Hochschild, Arlie. 1997. The Time Bond: When Work Becomes Home and Home Becomes Work. New York: Metropolitan Books.

Holstein, James A. and Jaber F. Gubrium. 1995. "Deprivatization and the Construction of Domestic Life." Journal of Marriage and the Family 57:894-908.

Hondagneu-Sotelo, Pierrette. 2001. Domestica: Immigrant Workers Cleaning and Caring in the Shadows of Affluence. Berkeley: University of California Press.

Karner, Tracy. 1998. "Professional Caring: Homecare Workers as Fictive Kin." Journal of Aging Studies 12:69-82.

Lamont, Michèle. 1992. Money, Morals and Manners: The Culture and the French and the American UpperMiddle Class. Chicago: University of Chicago Press.

- 2000. The Dignity of Working Men: Morality and the Boundaries of Race, Class, and Immigration. New York and Cambridge: Russell Sage Foundation and Harvard University Press.

Lan, Pei-Chia. 2000. Global Divisions, Local Identities: Filipina Migrant Domestic Workers and Taiwanese Employers. Ph.D. Dissertation, Department of Sociology, Northwestern University, Evanston, IL.

—_ 2003. “'They Have More Money but I Speak Better English!': Transnational Encounters Between Filipina Domestics and Taiwanese Employers." Identities: Global Studies in Culture and Power 10:13261.

Lasch, Christopher. 1977. Haven in a Heartless World. New York: Basic Books.

Lin, Jean Chin-Ju. 1999. Filipina Domestic Workers in Taiwan: Structural Constraints and Personal Resistance. Taipei: Taiwan Grassroots Women Workers' Centre.

McIntosh, Wm Alex. 1996. Sociologies of Food and Nutrition. New York and London: Plenum Press.

Mendez, Jennifer Bickham. 1998. "Of Mops and Maids: Contradictions and Continuities in Bureaucratized Domestic Work." Social Problems 45:1 14-35.

Momsen, Janet Henshall. 1999. Gender, Migration and Domestic Service. London and New York: Routledge. 
Nippert-Eng, Christena. 1995. Home and Work: Negotiating Boundaries through Everyday Life. Chicago: University of Chicago Press.

Ozyegin, Gul. 2001. Untidy Gender: Domestic Work in Turkey. Philadelphia: Temple University Press.

Parrenas, Rhacel Salazar. 2001. Servants of Globalization: Women, Migration and Domestic Work. Stanford: Stanford University Press.

Rollins, Judith. 1985. Between Women: Domestics and their Employers. Philadelphia: Temple University Press. Romero, Mary. 1992. Maid in the U.S.A. London and New York: Routledge.

Salzinger, Leslie. 1991. "A Maid by Any Other Name: The Transformation of 'Dirty Work' by Central American Immigrants." Pp. 139-60 in Ethnography Unbound: Power and Resistance in Modern Metropolis, edited by M. Burawoy. Berkeley: University of California Press.

Schwartz, Barry. 1968. "The Social Psychology of Privacy." American Journal of Sociology 73:741-2.

Skolnick, Arlene S., ed. 1992. The Intimate Environment: Exploring Marriage and the Family, Fifth Edition. New York: Harper Collins Publishers.

Thorne, Barrie. 1993. Gender Play: Girls and Boys in School. Brunswick, NJ: Rutgers University Press.

Yeoh, Brenda and Shirlena Huang. 1998. "Negotiating Public Space: Strategies and Styles of Migrant Female Domestic Workers in Singapore." Urban Studies 35:583-602.

Zerubavel, Eviatar. 1981. Hidden Rhythms: Schedules and Calendars in Social Life. Chicago: University of Chicago Press. 